\title{
Do Institutions Matter?
}

\section{Estimating the Effect of Institutions on Economic Performance in China* \\ Ying Fang Yang Zhao \\ WISE, Xiamen University}

June 5, 2009

\begin{abstract}
This paper estimates the effect of institutions on economic performance using cross-city data from China. We argue that China's ongoing reforms are part of a long and circuitous historical transition from antiquity to modernity, which started about 150 years ago. Learning from Western countries has been a central aspect of this historical process. The West had a large influence on the early stage of this transition, which has persisted to current reforms. This study uses the enrollment in Christian missionary lower primary schools in China in 1919 as an instrument for present institutions. Employing a two-stage least squares method, we find that the effect of institutions on economic performance in China is positive and significant. The results are robust according to various tests including additional controls, such as geographic factors and government policy-related variables.
\end{abstract}

Key words: Institutions, Christian, Geography, Policy

JEL Classification: O11, O53, P16, P51

Authors: Ying Fang, Corresponding author, Wang Yanan Institute for Studies in Economics (WISE), Xiamen University, Xiamen, 361005, China (e-mail: yifst1@gmail.com).

Yang Zhao, Wang Yanan Institute for Studies in Economics (WISE), Xiamen University, Xiamen, 361005, China (e-mail: econbird@hotmail.com).

\footnotetext{
* We thank Thomas Rawski for directing us to the data on Christian history in China and Chun-Chung Au and Vernon Henderson for sharing geographic data on China with us. We also acknowledge helpful comments from Daniel Berkowitz, Alexis Leon, Marla Ripoll, and the participants at the 2007 Econometric Society North American Summer meeting, the 2008 Ronald Coase Institute Summer workshop, and the 2009 BOFIT seminar on long-term economic growth in Russia and China.
} 


\section{Introduction}

China's real GDP per capita has been growing at an average rate of about $7.4 \%$ for almost thirty years ${ }^{1}$. While some suspect that China's GDP numbers have been exaggerated, the impressive economic growth of China is a widely recognized statistical fact. China's economic success is generally attributed to the reform and opening policies in place since 1978, which have transformed the economy towards a market system in a step-by-step fashion. However, the results of this reform have not been evenly distributed across the country. A country with a size close to Europe with one-fifth of the world's population, China contains more than 300 cities with substantial variations in both production and institutions. For example the 2003 GDP per capita in Shenzhen, one of the fastest-growing cities in China, was 54,545 yuan, while it was 8,077 yuan in Chongqing, a city located in the mountainous area of Southwestern China. Different measurements show large variations in institutions among regions. For example, according to the Marketization Index constructed by Fan et al (2003), Guangdong was assigned a value of 8.41 in 2000, while Xinjiang had a value of only 3.15. Research from the World Bank estimates that 80 percent of the productivity gap among cities could be explained by the investment climate (World Bank, 2006). This paper tries to estimate the effects of institutions on China's economy using cross-city data.

The topic of this paper thus relates to a general issue regarding economic development: how can we understand the large spatial differences in economic performance? Economists have offered various explanations. Many researchers believe that economic performance is rooted in the economic decisions of millions of individuals. When making economic decisions about investment, education or $R \& D$ (research and development), people and firms respond to incentives created by societal institutions. Therefore, some have argued that institutions are the most important determinant for economic development (North and Thomas, 1973; North, 1981 and 1990; Easterly and Levine, 2003; Acemoglu, Johnson and Robinson, 2001, 2004, 2005; Acemoglu and Johnson, 2005; Rodrik et al., 2004). In contrast, some scholars suggest that

${ }^{1}$ According to the National Bureau of Statistics of China, China's GDP per capita increased from 381 yuan in 1978 to 14,040 yuan in 2005. The Consumer Price Index increased from 100 to 464 during the same period (National Bureau of Statistics of China). 
geography shapes human history and plays a fundamental role in economic growth (Diamond 1997, Sachs and Warner 1995, 1997). Others argue that human capital and government policies are the most important determinants of development (Glaeser et al., 2004). China provides a compelling setting to compare the effects of institutions, geography and policies. In addition to regional variation in production and institutions, China exhibits large differences in geography and government policies across localities. Compared with a cross-country study, one merit of considering the Chinese case alone is that there is only economy to consider with a uniform currency, legal system, trade regime and historic-cultural background, allowing for a comparison of the effects of institutions, geography and policies with less noise due to other potentially influential factors.

One difficulty in estimating the effects of institutions is that institutions are endogenous. Richer economies are able to provide better education systems, more lawyers and prosecutors, better educated government officials, better public media and so on, resulting in better institutions. Moreover, there may be other factors, such as geography, that affect both institutions and economic performance. Because of the endogeneity of institutions, the OLS estimate of the effect of institutions on economic performance is biased, making it impossible to determine the causal relationship between institutions and economic performance. In order to obtain a consistent estimator, it is necessary to use an instrumental variable for institutions.

Econometrically, estimating the effects of institutions on economic performance requires developing instruments for institutions. Mauro (1995) used ethnolinguistic fractionalization as an instrument to analyze corruption and bureaucratic efficiency. Hall and Jones (1999) used distance from the equator across countries as an instrument for social infrastructure. Acemoglu et al. (2001) employed European settler mortality rates as an instrument for institutions. However, there are some concerns regarding the validity of these instruments. Some authors have argued that ethnolinguistic fractionalization is influenced by economic performance (Acemoglu et al., 2001). Distance from the equator can affect the economy through climate and geography rather than through institutions (Bloom and Sachs 1998; Gallup et al., 1999). Glaeser et al. (2004) argued that historic rates of European settler mortality were correlated with the current disease environment 
and human capital, which could influence current economic performance directly rather than through institutions.

We adopt the enrollment in Protestant missionary lower primary schools in the early $20^{\text {th }}$ century as an instrumental variable for China's present institutions. Our logic is summarized in three arguments:

1. China's present reform can be viewed as part of longer historical movement toward "modernization," which can be traced back at least 150 years. The main feature of this movement involves learning from the West to transform China from a pre-modern to a modern economy.

2. Those geographic areas that have experienced a deeper historical influence from the West have developed institutions more favorable to a market economy and the protection of property rights.

3. The enrollment in Protestant missionary lower primary schools in 1919 reflects the influence of the West in early $20^{\text {th }}$ century China.

We can sketch our logic as follows: the influence of the West $\Rightarrow$ influences on institutions $\Rightarrow$ influences on economic performance. We perform a two-stage least squares (2SLS) estimation and find that institutions are significant in explaining the variation in economic performance across the Chinese cities in our sample. The results are robust to various tests and show that institutions dominate geography and policy in explaining the economic variation among Chinese cities.

The rest of the paper proceeds as follows. Section 2 introduces the historical background of China's institutional changes. Section 3 discusses our strategy to develop an instrument to identify the impact of institutions on China's economic growth. Section 4 describes the measurements we adopt in this paper as well as our data set. In section 5, we estimate the effect of institutions on economic performance and check for robustness. Section 6 compares the effect of institutions with those of geography and policy. Finally, section 7 provides a conclusion. 


\section{Institutional Change in China: A Brief Historical Background}

Although China's current reform started in 1978, many historians see this reform as the most recent dimension of a much longer and greater transitional process (Ray Huang, 1988; Degang Tang, 1998). This process dates back to 1553, when China allowed the Portuguese to anchor and trade at Macau, and it particularly accelerated after China experienced a series of military defeats to Western countries during the second half of the $19^{\text {th }}$ century. Following the imposition of a free trade regime on China at several port cities, local Chinese markets became integrated with the international economy and markets at least by the 1890s (Brandt, 1985). Many Chinese then realized that China had to learn from Western culture in order to modernize its social system, which resulted in the introduction of modern industries into China. This process suffered many setbacks, but after the settlement of the Boxer turmoil of 1900 that led to the occupation of Beijing by eight Western countries, Western observers viewed China as having entered a new era. Although it echoes the current news coverage of China, the following remark is in fact a description by a Christian observer writing in 1919:

"The two decades have been distinctly revolutionary in tendency: this not in the old sense alone which resulted in the displacement of individuals, but deeper, in that during this period ancient principles and institutions have been moved aside for something new. ... More significant than any other change has been that in the temper of the people. After all, the changes already registered are precursors of wider ones. China will not only reflect the changes going on all over the world but will materially help to change the world. Four hundred million people cannot wake up and leave the rest of the world untouched" (Rawlinson, 1922).

In 1911, the Qing Dynasty became the final dynasty in China's history as it was overturned by the Xinhai Revolution and succeeded by the Republic of China. After the revolution and World War I, China experienced a rapid industrial spurt. The following quote provides a rough but impressive picture of the economy during the early years of the Republic of China.

"The coming of modern industry to China has been described as 'terrific invasion'. This modern revolution is taking place so quietly that few people are aware that anything untoward is happening. To estimate the growth in terms of figures is not easy, since no authentic and complete 
list of factories has as yet been published. In the China Year Book of 1921 a list of "the more important trades" is given, showing that almost every type of industry is to be found in China, e.g. Arsenals, Canneries, Cement Work, Confectionery, Cotton, Chemicals, Breweries, Dockyards, Shipbuilding, Engineering, Flour Mills, Furniture, Glass, ...This list does not include certain industries with which the name of China is particularly associated, e.g. Carpets, Rugs, Porcelain, etc. The above are listed under some 50 centers scattered over China. The secretary of the Chinese Maritime Customs says, "There are foreign-type articles of domestic consumption that are not now manufactured in China by factories on modern lines, the majority without foreign assistance. For proof of this mushroom-like growth, return visits to some of our factory districts after an interval of a few months will suffice, or reading the notes under 'Industry in China' which appear in the Far Eastern Review or in the Weekly Review of the Far East from time to time" (The Christian Occupation of China, 1922).

At that time, it seems that China was experiencing an early phase of what Kuznets terms modern economic growth. Railroads were expanded, and factories were erected. Between 1913 and 1920, Chinese managers established 1,061 modern factories, employing over a quarter million workers with a capital investment totaling around 170 million Chinese dollars² (Myers, 1980, pp. 126). This development continued until World War II. According to John K. Chang's index of industrial production between 1911 and 1949, both the gross and net value production showed a rapid annual growth rate of around 9.4 percent from 1911 to 1936 (Chang, 1969). This growth rate is higher than that of the United Kingdom (1820-1870, 3.0 percent), the United States (1860-1914, 5.9 percent), and Japan (1906-1935, 6.4 percent) (Myers, 1980, pp.135-136).

However, the transition process was interrupted by the battle against Japanese invaders from 1937 to 1945 and the subsequent civil war between the Kuomintang government and the Chinese Communist Party (CCP) from 1946 to 1949. When the civil war ended in 1949, the Republic of China moved to Taiwan, while the mainland was governed by the People's Republic of China. China continued to learn from the West, however, but this time from Karl Marx. The CCP copied the economic model of the Soviet Union and transformed the Chinese economy by embracing

\footnotetext{
${ }^{2}$ One Chinese dollar equaled 0.26 USD in 1933 (Myers, 1980, pp. 251).
} 
central planning. The CCP government promoted manufacturing through high compulsory savings and distorted the low price of inputs. China built a rather complete sector of heavy industries, including oil, steel, ship and even aviation. However, a substantial gap is believed to have existed between China's economic performance and its potential during the planned economy era (Brandt and Rawski, 2008).

In 1978, when DENG Xiaoping became the leader of the party, China began a series of reforms that gradually moved the planned economy towards a market-oriented system. In 1978, millions of farm households regained certain freedoms to manage agricultural production. Thousands of Chinese students were sent to universities in Western countries. State-owned enterprises began to publicly recruit managers in 1983 and then to issue stocks in 1987. In 1990, the public stock exchange was established. At the same time, privately owned and village-owned enterprises (TVEs or Xiangzhen Qiye) were encouraged and subsequently prospered. Between 1978 and 2005, China's trade volume increased 68-fold in terms of US dollars. The FDI into China increased from 2.65 billion US dollars in 1984 to 189.06 billion US dollars in 2005 (National Bureau of Statistics of China). In 2001, China was accepted as a member of the WTO.

In short, China's current reforms can be viewed as part of a long and winding road of "modernization" characterized by "learning from the West." Based on this historical view, we believe that influence from the West during the early decades of the $20^{\text {th }}$ century has had a significant influence on China's current economic performance.

\section{The Instrument Used to Measure China's Institutions}

Before estimating the effects of institutions, we must consider how to define institutions. The term "institutions" is a concept that can include many phenomena, from general law to cultural conventions. Following North and Thomas (1973) and North (1981, 1990), our hypothesis is that the protection of property rights is key to explaining economic performance. Thus, we consider institutions as sets of social rules that protect property rights. Also following North (1981), the practical rules enacted during enforcement rather than the rules merely written on paper are most 
relevant. One report from the World Bank supports this argument, saying, "It is not just formal policies that matter. The implementation of policies is what is experienced -- with 95 percent of firms reporting a gap between what is on the books and how regulations are interpreted in practice. This gap provides a key opening to corruption and by raising uncertainty lowers the probability of investment by up to a third" (World Bank, 2006). Therefore, we focus on the implementation of property rights protection as an institution.

China's ongoing changes can be collectively viewed as a transition from a planned economy to a market economy during which property rights are given increasing levels of respect and protection. Although different localities within China share a uniform political and legal system on paper, actual institutions - that is, the practical enforcement of the market system -- show large variations across regions. For example, the list of China's 100 most competitive private firms in 2005 shows that the vast majority are based in just 3 of 32 provincial administrative regions in China's mainland, with 37 firms on the list from the Zhejiang province, 16 from Guangdong, and 10 from Jiangsu (Liu, Zhao and Liu, 2007).

How can China, a country with such a strong central government and such a uniform constitution and legal system, present so large a regional variation in institutions? First, although the reform and opening policies have been adopted by the central government, many specific reforms were initiated by local governments. Beneath the uniform political and legal system, the extent to which people engage with the market is largely determined by their confidence in the protection of property rights by the local administrative practice, which is highly influenced by local conventions and understandings. These local conventions result from the unique historical evolutions of local communities. We believe that current conventions are related to the historical influence of the West on local communities in the early $20^{\text {th }}$ century. Since the modern market system and the protection of property rights are institutional establishments originating from Western countries, regions with longer histories of influence from the West should experience greater penetration in terms of market institutions.

We use enrollment in Protestant missionary lower primary schools to capture the extent of Western influence. The earliest Christian mission in China can be traced back to 1582, when 
Matteo Ricci came to China. However, organized missionary activities began after 1841, paralleling the process of China's active learning from Western countries. During the Boxer turmoil in 1900, the Christian Church was largely destroyed in some areas. However, the Church soon rapidly recovered. Thus, Christian missions developed quickly during the early years of the Republic of China. Almost every province had Christian missionary centers, and almost every mission station had a lower primary school. Historically, Christians represented Western culture, so the extent of local Christian influence can serve as a measure of how much an area was influenced by the West.

Since current institutions are related to the historical influence of the West, early Christian influence can serve as an instrument for today's institutional property rights protection. The data on our instrument is described in the next section. Panel A of Table 2 shows that the institutions under study are significant when regressed using the log GDP per capita in 2003. However, due to the endogeneity of institutions, this result should be read as a relationship of correlation rather than causality. Panel B of Table 2 shows that our instrument is significant as an explanatory variable for present institutions.

The so-called "exclusion condition" with respect to using an instrument assumes that the instrument only affects current economic performance through institutions. To investigate whether this condition holds, we consider two possible violations of the exclusion condition. One concern is whether the historical enrollment of the Protestant missionary lower primary schools could affect the current distribution of Christianity in China, with the current Christian religion in turn affecting economic performance directly rather than through institutions. Missionary schools taught not only religious subjects but also curricula about Western epistemology. Long before 1927, the number of required hours of Bible study in missionary primary schools had been reduced (Idabelle Lewis Main, 1934, pp. 270). The new curricula focused more on citizenship training and the Chinese language (Howson Lee, 1934). Kiang-wen Han (1934, pp. 313) concluded that "on the whole, religion does not hold an important place in the life and thinking of the students in China." Moreover, after 1949, the level of influence of all religions in China declined due to government-enforced atheist ideology and the suppression of religion during the 
Cultural Revolution between 1966 and 1976. The recent revival of religion in China since 1978, which has included Christian missionaries, is difficult to measure. Besides the authorized missionary activities, there are variant forms of unauthorized missions, including overseas missionaries and underground churches. In general, we believe that the historical legacy of Christianity in China has little impact on the current incarnation of Christianity in China.

More importantly, as Barro and McCleary $(2005,2006)$ argued, it is a general belief in God, the afterlife, heaven and particularly hell, rather than organized religious activities, that positively affect economic performance. Using cross-country data, Barro and McCleary (2005) found that after controlling for belief in heaven or hell, the Protestant religious population actually detracts from economic growth. The Chinese have a long history of belief in heaven, hell and the afterlife that dates back to the Han Dynasty (206 B.C. - 220 A.D.) and earlier (Yu, 1964, 1987). The introduction of Buddhism into China since the late Han Dynasty and its subsequent popularity has spread a belief in hell and the afterlife across China. Compared with Buddhists or with the mass of believers in hell and the afterlife, Christians are a small minority in China. We therefore believe that the enrollment in Protestant missionary primary schools in 1919 has very little influence on current Chinese beliefs about heaven or hell and does not directly affect current economic performance.

We perform an intuitive test regarding whether our instrument affects current log GDP per capita directly. If the historical enrollment in Protestant missionary lower primary schools (our instrument) only affects current log GDP per capita through institutions, then our instrument should be significant when explaining log GDP alone but not significant when explaining log GDP along with other institutions. We see this exact outcome in panel A of Table 2. When we regress $\log$ GDP per capita in 2003 on our instrument alone, the coefficient of our instrument is 0.18, which is significant at the 5\% level. However, when we regress log GDP per capita in 2003 on both the average protection of property rights and the historical enrollment of missionary lower primary schools, the coefficient of our instrument is not significant, while the coefficient of the average protection of property rights remains significant at the $5 \%$ level. 
The other concern about the violation of the exclusion condition is that the instrument is correlated with other unobserved determinants of economic performance. We test three possible underlying factors. First, if Christian missions were more prevalent in coastal areas than in inland areas, then our instrument could be correlated with distance to the coast, which could possibly affect GDP per capita across regions through several other channels, such as the acquisition of FDI and access to international trade. Thus, our instrument could affect economic performance through distance to the coast rather than through institutions. However, the distribution of Christian missionaries in 1919 does not correlate with distance to the coast. The Treaty of Tientsin between China and France in 1860 allowed Christian missions to establish their missionary stations far from the coast. The Most Favored Nation Clause enabled all Western countries to locate missions in China's hinterland. As Feuerwerker (1983, pp. 165-167) has described, "Protected by general and specific extraterritorial provisions of treaties, they reached into nearly every corner of the country. As of 1899 all but 106 out of 1704 counties or hsien in China proper and Manchuria reported some Protestant missionary activity." Panel B of Table 2 adds distance to the coast as an additional control in our regression of institutions and finds that our instrument is still significant in explaining institutions when distance to the coast is controlled.

The second possible underlying factor is that the historical distribution of Protestant primary school pupils may affect the current economy through the channel of human capital. If higher enrollment means better educational conditions and higher human capital in the 1920s, then our instrument could influence current economic performance through historical human capital rather than through institutions. However, we believe this cannot be the case for the following reasons. Missionary lower primary school pupils were only around $4 \%$ as many as those in government primary schools in the 1920s (Albert Feuerwerker, 1983). We check this by regressing our instrument on the total primary school enrollment, which we employ to capture human capital in the 1920s. The result is reported in panel C of Table 2. There is no significant correlation between the two variables.

\section{Measurements and Data}

China's sub-national governments can be categorized into four administrative levels: 
province, city, county and town/village. There are only 34 observations $^{3}$ at the provincial level. In the early 1900s, China had only 18 provinces, some of which have since been divided and merged into others. Using city-level data, we obtain more observations. Our sample consists of 47 cities as listed in Table A2. The sample size is restricted by the institutional data. One complicated issue is that city boundaries have changed substantially during the last 100 years. The data on the historical enrollment in Protestant missionary primary schools are at the county level. Since the county boundaries have been rather stable during the entire $20^{\text {th }}$ century, the county-level data on Christian missions can be matched with the city-level data on institutions.

As mentioned above, this paper focuses on institutional property rights protection. We note that it is always difficult to measure institutions. There are two basic methods to measuring institutions. One is a subjective measurement in which people's opinions about institutions are evaluated through a survey and then aggregated into a quantitative index. The alternative is an objective measurement based on statistical facts on the effects of institutions. For example, the wait time for obtaining government approval to start a business can be observed and used as a measurement for institutions. This paper uses a subjective measurement. The data are from a cross-city survey conducted by Pengfei Ni et al. in 2002 and 2003 (Ni et al, 2003, 2004). The survey covered 47 cities at the prefectural or higher levels. For each city, 2000 questionnaires were sent to scholars, entrepreneurs and randomly sampled citizens asking them to grade the city's performance in a wide range of aspects. For each listed item, the respondent selected from five options ranging from highest (favorable) to lowest (unfavorable). Ni et al set the highest option at 1.5, while the lowest was set at -1.5 . For each item, they calculated the mean score and then constructed an index ranging from 0 to 1 across 47 cities.

This paper focuses on the index of property rights protection developed by Ni et al. This includes three sub-indices, namely, the extent to which the government resorts to informal tax levies, the protection of intellectual property rights, and the protection of contract enforcement by

\footnotetext{
${ }^{3}$ Overall, China has 34 provincial level sub-national governments, including 23 provinces, 5 autonomous regions, 4 province-level cities and 2 special administrative areas, Hong Kong and Macau.
} 
the legal system. We take the average of their index of property rights protection for 2002 and 2003 as our main measurement. The city with the highest average is Xiamen at 0.896 , and the lowest rated city in the sample is Wuhan at 0.5035 . We find that among the top 10 cities with the highest average indices, 7 are from Zhejiang, Jiangsu and Guangdong provinces. These areas also had the most competitive private enterprises in China in 2005 according to Liu et al. (2007).

$\mathrm{Ni}$ et al. also constructed an index for comprehensive institutions and a sub-index for informal government collection and fees. We use these two indices as complementary measurements to check the robustness of our results.

The data on the historical enrollment of Protestant missionary lower primary schools is from a survey conducted by the Continuation Committee in 1920. The results of this survey were edited into a book titled "The Christian Occupation of China." The survey results include all county-level data on the enrollment of Protestant missionary lower and higher primary schools in 1919. We choose only the lower primary school data because the data on higher primary schools are rather incomplete. For example, there were only 306 higher primary schools reported out of the 693 Protestant residential centers (Feuerwerker, 1982). Since the survey includes the population for each county as well, we can calculate the enrollment in missionary lower primary schools per 100,000 persons, which thus serves as our instrumental variable for institutions.

Finally, to measure economic performance across regions, we use the log GDP per capita for all cites in 2003 following Hall and Jones (1999). These data are obtained from the Urban Statistical Yearbook of China 2005 in terms of the Chinese yuan. In Table A1, we describe all other variables used in this paper and list the data sources.

Table 1 provides descriptive statistics on our main data. The average of the log GDP per capita for all 47 cities in 2003 is 10.048, and the standard deviation in the sample is 0.4842 . The maximum observation is 11.004 , while the minimum is 8.996 , which means that the GDP per capita of the richest city in our sample is almost 7.5 times that of the poorest city in 2003 . The sample mean of the average protection of property rights is 0.6509 , and the standard deviation is 
0.0979. The average enrollment in missionary lower primary schools is 72.258 per 100,000 persons, and the standard deviation is 84.656 . The maximum observation is 420.223 per 100,000 persons, while the minimum is only 1.3828 per 100,000 .

\section{Empirical Results}

\subsection{The Model}

Although institutions are significant in the OLS regression reported in panel A of Table 2, this result should be read as no more than a correlation. No causal relationship can be inferred between institutions and economic performance from OLS estimates. Moreover, due to the endogeneity of institutions, the OLS estimate is biased. Hence, we use a two-stage least squares (2SLS) method to estimate the effect of institutions on economic performance. The basic model is

$$
\begin{aligned}
y_{i} & =a+\beta I N S_{i}+\theta X_{i}+\varepsilon_{i} \\
I N S_{i} & =b+\gamma E_{i}+v_{i},
\end{aligned}
$$

where $y_{i}, I N S_{i}$ and $E_{i}$ denote the log GDP per capita in 2003, the average protection of property rights in 2002-2003, and the historical enrollment of missionary lower primary schools for city $i$, respectively. We use $X_{i}$ to denote other control variables, such as distance to the coast, rainfall, temperature, approximate historical human capital, government policy and so on. In the first stage, we regress the observed measure of current institutional performance on our instrumental variable $E_{i}$ and the covariates $X_{i} \cdot v_{i}$ comprise the error term. In the second stage, we regress the current GDP per capita $y_{i}$ on the predicted institutions derived from the first stage with $\varepsilon_{i}$ as the error term. Covariates $X_{i}$ appear in both regressions. The parameter of interest is the coefficient $\beta$ in Equation 1, which is the effect of the institution under study on economic performance. Note that the historical enrollment distribution of missionary lower primary schools is not correlated with the structural error term in the second stage. 


\subsection{Main Results}

Table 3 lists our main findings regarding the effect of institutions on economic outcomes. Panel A lists the estimation results from the second stage regression with the log GDP per capita in 2003 as the dependent variable. Panel B lists results from the first-stage regression with average protection of property rights as the dependent variable. Table 3 presents the main specification with the enrollment in Protestant missionary lower primary schools as the instrument for institutions. The 2SLS estimate of the institution under study is 4.23 , which is significant at the 5\% level for a two-sided t-statistic.

Compared to the OLS estimate in panel A of Table 2, there are two noteworthy points. First, the institution coefficient is significant in both regressions. The coefficient in the 2SLS regression is 4.23 , which implies that the city's GDP per capita will increase by $4.23 \%$ if its average index of property rights protection increases by 0.01 . For example, if Tianjin could improve its property rights to Beijing's level, that is, from 0.64 to 0.68 , then its GDP per capita would increase by about $17 \%$. Second, the value of the coefficient in the 2SLS is much larger than in the OLS regression. From this perspective, our results are similar to those of Acemoglu et al. (2001), as their 2SLS results are twice those generated from OLS. This shows that the OLS estimate of the effect of institutions is downward biased, which is the same as the findings presented by Hall and Jones (1999) and Acemoglu et al. (2001).

We also report the value of the Anderson canonical correlation likelihood ratio test (Hall et al., 1996). The null hypothesis of the test is that the first-stage regression is underidentified, i.e., that the instrument is not relevant. Under the null hypothesis, the test converges to a Chi-square distribution with one degree of freedom. The Anderson canonical correlation LR test reported in column (1) is 7.491. The small p-value of 0.006 indicates that we can confidently reject the null hypothesis. 


\subsection{Possible Violations of the Exclusion Condition}

Section 3 discussed concerns about the validity of the exclusion condition for our instrument with several intuitive OLS regressions. As a robustness test, we insert additional right-hand variables into the 2SLS as additional controls to test the validity of our instrumental variable. If the exclusion assumption holds, the institution coefficient in the second-stage regression should not change remarkably when additional controls are added to the regression. The results are reported in Table 4. In column (1), distance to the coast is added as an additional control for both stages. In the first stage, both the historical enrollment of missionary lower primary schools per 1000 persons and distance to the coast are significant. In the second stage, the institution coefficient is 3.779 and is still significant, but the coefficient of distance to the coast is not significant. This shows that distance to the coast is not significant in explaining the log GDP per capita when institutions are considered.

Column (2) addresses the concern that our instrument might be correlated to the historical geographic distribution of human capital, which affects current economic performance. It is difficult to find data on historical human capital. We approximate this information with the total primary school enrollment per 1000 persons, which includes the historical enrollment of lower and higher primary schools of both missionary and government schools per 1,000 persons in 1919. In the first stage, we find that only the enrollment of missionary lower primary schools helps to explain the variation of institutions across regions and that the total enrollment is not significant. In the second stage, the institution coefficient is 4.304 and is significant at the $5 \%$ level, while the control variable is not significant.

In column (3), we examine the possible correlation between the historical geographic distribution of enrollment in Protestant missionary lower primary schools and the initial conditions of different cities before the reform. We use the earliest available cross-city data on national income ${ }^{4}$ to measure the initial conditions in $1985^{5}$. The first-stage regression shows that both the

\footnotetext{
${ }^{4}$ We calculate national income as the sum of gross agricultural output values and value added in industry for each city. The national income per capita is the national income divided by each city's population in 1985 .
} 
instrument and initial conditions before the reform are significant. In the second-stage regression, the institution coefficient is 4.115 and is still significant at the $5 \%$ level, while the initial condition is not significant. In column (4), we consider both distance to the coast and initial conditions together as the control variables. The 2SLS shows that neither of the two controls is significant, while the institutions under study remain significant. Overall, our estimates for institutions are rather stable in all specifications, supporting the argument that our instrument is valid.

\subsection{Different Measurements of Institutions}

We also test whether our result is robust to the measurement of the institution under study. One difficulty in estimating the impact of institutions lies in how to measure the institutions themselves, and in our case, how to measure the institution of protecting property rights. The measurement of this institution is always controversial. Whatever measure is adopted, there will always be some unsatisfactory aspects.

As explained in the previous section, our main specification uses the average of the index of property rights protection according to two surveys by Ni et al. (2003, 2004). Ni et al $(2003,2004)$ also provides some other measures, such as the comprehensive index of institutions and the index for government collection of informal fees, which represents an abrogation of property rights. The comprehensive index is the general index based on a series of sub-indices that measure various aspects of each city's legal, government and enterprise systems. The index showing the prevalence of informal fees measures the extent to which the government imposes extra-legal charges on private businesses. Table 5 reports the results when those different variables are used to measure institutions. Panel A reports the effects of institutions on the log GDP per capita when the measurements listed on the left are used. Institutions are significant with all three measurements. Panel B reports the result of the first-stage regression when the protection of property rights is a dependent variable measured by the variables listed on the left. In all cases, our instrument is significant in explaining institutions.

\footnotetext{
${ }^{5}$ The urban economic reform in China had not been launched on a large scale until 1985.
} 


\section{Institutions, Geography and Policy}

\subsection{Institutions versus Geography}

As mentioned in the introduction, geography may play a role in background, thus influencing economic development. Table 6 reports the results of adding geographic controls. One of most popular geographic variables used in the literature is latitude. In column (1), latitude is added to the regression. The inclusion of latitude does not substantially change the results. The institution coefficient remains significant and takes on a value of 3.559. Latitude is not significant in the second-stage regression, nor is it helpful in interpreting the variation of institutions in the first-stage regression. Other geographic variables include average temperature and rainfall. Column (2) adds average temperature as a control. In the second stage, we find that the institution and average temperature coefficients are 3.400 and 0.027 , respectively, and that both estimators are significant. However, the average temperature is not significant in the first-stage regression, i.e., it does not help us to interpret the variation of institutions across regions. In column (3), rainfall is added to the regression. The institution coefficient is significant and takes on a value of 3.949. Rainfall is not significant in either stage.

Besides institutions, another channel that may have an effect on today's economy is through culture, which is nonetheless geographically related. Therefore, we test our argument by controlling for culture across localities. Given the complicated cultural differences across various localities in China, the most prominent is the cultural difference between the North and South as divided by the Yangzi River, which is discussed by Diamond (1997). Thus, in column (4), we use a north-south dummy as another control variable. If a city is located south of the Yangzi River, we set the dummy to 1 and 0 otherwise. The institution coefficient is 3.950 and significant at the $5 \%$ level. The south-north dummy is not significant in either stage and thus does not help us to understand the variation of institutions across localities. In column (5), all these geographically related variables are added to the regression. The institution coefficient is significant and takes a value of 3.479. No other coefficients are significant. 
Overall, adding geographically related variables does not have a significant effect on the institution estimates. The institution estimates instrumented using the historical distribution of enrollment in missionary lower primary schools are rather stable and always significant, as shown in Table 6.

\subsection{Institutions versus Policies}

Some economists have argued that government policy is more important than institutions in promoting economic growth (Edward Glaeser, et al., 2004). To test this argument in the case of China, we add some policy variables to the main specification of 2SLS regression. One policy variable we use is the dummy variable for central government policy. For a long period, China was divided into three regions in terms of economic policy, namely, eastern, central and western regions, each of which was assigned a specific economic task. ${ }^{6}$ Although the income per capita varies greatly across the country, it exhibits convergence within each of these three regions. Some believe this is due to the different development strategies adopted by the government for different regions (Lin, 2004). For example, the eastern region enjoys a more favorable policy for the development of light industries, while the central and western regions have long been focused on agriculture and heavy industries. We use two dummies to capture a city's policy zone, namely, east and west. If a city falls in the east zone, its east dummy is set as 1 , and its west dummy is set as 0 . If a city falls into the west zone, its east dummy is 0 and west 1 . If a city falls into the middle zone, then both dummies are set equal to 0 . The results reported in column (1) of Table 7 show that none of the zone dummies are significant in the second stage, while the average protection of property rights is still significant, with a coefficient of 3.866. In the first stage, our instrument is still significant in interpreting the variation of institutions across regions, and the coefficient is relatively stable. The west dummy is not significant in the first stage. The east dummy is significant with a value of 0.107 in the first stage. Thus, it seems that the central government

${ }^{6}$ In this paper, the eastern region includes Beijing, Tianjin, Shanghai, Hong Kong, Macau, Liaoning, Shandong, Jiangsu, Zhejiang, Fujian, Guangdong, and Hainan. The central region includes Hebei, Shanxi, Neimenggu, Jilin, Heilongjiang, Anhui, Jiangxi, Henan, Hunan, and Hubei. The western region includes Guangxi, Yunnan, Guizhou, Sichuan, Chongqing, Shaanxi, Gansu, Ningxia, Qinghai, Xingjiang and Xizang. Taiwan is not included in our analysis here. 
development policy is not the main explanation for the difference in GDP across the cities in our sample.

Column (2) of Table 7 includes a dummy for open coastal cities as an additional control. Open coastal cities have benefited from more favorable policies regarding economic reform and development. When the dummy for open coastal cities is included, the coefficient of institutions is 4.405 and is significant at the $5 \%$ level in the second-stage regression. The coefficient of the dummy for open coastal cities is not significant in either stage.

China's cities have different administrative ranks. The top rank includes provincial-level cities (zhixiashi), such as Beijing, Tianjin, Shanghai and Chongqing. The second rank is the deputy-provincial level (fushengji) cities, and the third rank is the prefectural-level cities (dijishi), which includes all cities outside the top 2 ranks. The fourth-rank cities are below the prefectual level, i.e., county-level cities (xian). The 47 cities in our sample are all from the top three administrative ranks. A higher administrative rank usually means greater political power in competing for economic resources and more favorable policies from the central government. In column (3) of Table 7, we construct a dummy for provincial and deputy-provincial-level cities and include it in the regression as an additional control. The dummy takes a value of 1 when a city belongs to a provincial or deputy-provincial level. When the dummy for the provincial and deputy-provincial levels is controlled, the institution coefficient is 4.249 and is significant at the $1 \%$ level. The dummy for the provincial and deputy-provincial levels is not significant in both stages. In column (4), we control for the above two dummies in the regression at the same time. We find that only the institution coefficient is significant at 4.393 .

In the literature on empirical economic growth, the ratio between government consumption and real GDP is used to measure the extent of government involvement (Barro, 2000). In column (5), the ratio between government consumption and real GDP is included as an additional control. The institution coefficient is significant with a value of 4.035 . The ratio between government consumption and real GDP is not significant in either stage. 
The investment rate is considered to be important for developing countries. We also examine the investment ratio to GDP as an underlying factor. However, when we regress our instrument on the investment rate for 2004, we find that there is no significant correlation between the two. When the investment rate is added as an explanatory variable, we find that our instrument is still significant in explaining the institution under study at the $1 \%$ level. Column (6) reports the result of adding the investment rate as a control. We find that both the institution under study and the investment rate are significant in explaining economic performance.

The results in Table 7 do not support the argument that policy plays a more important role than institutions in economic development. On the contrary, our results show that institutions rather than government economic policies account for China's economic performance.

\section{Conclusion}

Many economists believe that institutional change is a fundamental reason for China's impressive economic performance during the last twenty years. However, since institutions are widely believed to be endogenous, it is difficult to evaluate their effect. Following the method developed by Mauro (1995), Hall and Jones (1999), and by Acemoglu et al. (2001), we try to isolate the exogenous part of the variation in the institution of property rights protection across cities in China. We choose enrollment in Protestant missionary lower primary schools in 1919 as the instrument for China's present institutions. We believe that the enrollment in Protestant missionary lower primary schools captures the extent of influence from Western countries in the early $20^{\text {th }}$ century. Since the central aspect of China's institutional transition has involved learning from the West, the historical influence of the West in the early $20^{\text {th }}$ century may persist in China's current institutional changes.

Using cross-city data in China, we use the two-stage least squares method (2SLS) to estimate the effect of the institution under study on China's economic performance. The results show that a high correlation exists between the 1919 enrollment in Protestant missionary lower primary schools and present institutions. The 2SLS estimate shows that institutions are significant in 
explaining the variation of economic performance among our sample of 47 Chinese cities. Our estimate resembles the result of Acemoglu et al. (2001) in that the 2SLS estimate is much greater than the OLS estimate. The significance of the institution under study is robust to various tests that include control variables such as distance to the coast, historical human capital and initial conditions for different cities.

The paper also addresses the question of which element plays the most important role in economic performance. We compare the effect of institutions with that of geography and government policy. By controlling for geographic variables such as latitude, temperature, rainfall and north-south cultural differences, we find that institutions are significant, while geography is not significant, in explaining the variation of economic performance in our sample. When we control for government policies such as China's zone development policy, coastal city policy and government consumption ratio to local GDP, the institution under study is still significant, while government policies are not. These results support the hypothesis that institutions occupy a central role in determining economic performance.

\section{References}

Acemoglu, Daron, Simon Johnson. "Unbundling Institutions", Journal of Political Economy, 2006, Vol 113: 949-995.

Acemoglu, Daron, Simon Johnson and James Robinson. "Institutions as the Fundamental Cause of Long-Run Growth." Working Paper. 2004.

Acemoglu, Daron, Simon Johnson and James Robinson. "The Colonial Origins of Comparative Development: An Empirical Investigation", American Economic Review, 2001, Vol 91(5): 1369-1401.

Acemoglu, Daron, and Simon Johnson. "Unbundling Institutions", Journal of Political Economy, 2005, Vol. 113, 949-995. 
Acemoglu, Daron, Simon Johnson and James Robinson. "The Rise of Europe: Atlantic Trade, Institutional Change and Growth, American Economic Review, 2005, Vol. 95, 546-579.

Au, Chun-Chung and Vernon Henderson. "How Migration Restrictions Limit Agglomeration and Productivity in China", Journal of Development Economics, 2006, Vol 80(2): 350-388.

Barro, Robert J. "Economic Growth in a Cross-Section of Countries", Quarterly Journal of Economics, 1991, Vol 106(2): 407-443.

Barro, Robert J. "Inequality and Growth in a Panel of Countries", Journal of Economic Growth, 2000(5): 5-32.

Barro, Robert J. and Rachel M. McCleary. "Religion and Economic Growth.", Journal of Economic Perspectives, 2006, Spring.

Barro, Robert J. and Rachel M. McCleary. "Which Countries Have State Religions?", Quarterly Journal of Economics, 2005, November.

Bloom, David E. and Jeffrey D. Sachs. "Geography, Demography and Economic Growth in Africa", Brookings Papers on Economic Activity, 1998, (2): 207-273.

Brandt, Loren. "Chinese Agriculture and the International Economy, 1870-1930s: A Reassessment" , Explorations in Economic History, 1985, Vol. 22. pp. 168-193.

Brandt, Loren and Thomas Rawski. China's Great Economic Transformation, Cambridge: Cambridge Univ. Press, 2008.

Chang, John K. Industrial Development in Pre-Communist China, Chicago: Aldine. 1969. 
Diamond, Jared. Guns, Germs and Steel, New York and London: W.W. Norton \& Co. 1997.

Easterly, William. The Elusive Quest for Growth, Boston: MIT Press. 2002.

Easterly, William, Ross Levine. "Tropics, Germs, and Crops: How Endowments Influence Economic Development", Journal of Monetary Economics, 2003, 50: 3-39.

Fan, Gang, Xiaolu Wang, Liwen Zhang and Hengpeng Zhu. "Zhong Guo Ge Di Qu Shi Chang Hua Xiang Dui Jin Cheng Bao Gao." [The Report on the Regional Process of Marketization in China], Jing Ji Yan Jiu [Economic Research Journal ], 2003, No. 3. pp. 9-18.

Feuerwerker, Albert. "The Foreign Presence in China." edited by John K. Fairbank, The Cambridge History of China Volume 12: Republican China 1912-1949, Part 1, Cambridge: Cambridge University Press, 1983.

Gallup, John L., Andrew D. Mellinger and Jeffrey D. Sachs. "Geography and Economic Development". International Regional Science Review, Vol.22, No.2, 179-232, 1999.

Glaeser, Edward L., Rafael LaPorta, Florencio Lopez de Silanes, and Andrei Shleifer. "Do Institutions Cause Growth?", Journal of Economic Growth, 2004, Vol 9: 271-303.

Hall, Alastair R. Glenn D. Rudebusch and David W. Wilcox. "Judging Instrument Relevance in Instrumental Variables Estimation", International Economic Review, 1996, Vol 37(2): 283-298.

Hall, Robert, Charles Jones. "Why Do Some Countries Produce So Much More Output Per Worker Than Others?" , Quarterly Journal of Economics, 1999: 83-116.

Han, Kiang-wen. "Chinese Students and Religion." edited by Frank Rawlinson, The China Christian Year Book 1932-1933, Shanghai: Christian Literature Society, 1934. 
Huang, Ray. China: A Macro History, Turn of the Century Edition, Armonk (New York) and London: M. E. Sharpe. 1997.

Lee, Howson. "New Educational Trends." edited by Frank Rawlinson, The China Christian Year Book 1932-1933, Shanghai: Christian Literature Society. 1934.

Lin, Justin Yifu. Zi Sheng Neng Li, Jing Ji Fa Zhan Yu Zhuan Xing: Li Lun Yu Shi Zheng [Self-Support Ability, Economic Development and Transformation: Theoretical and Empirical Analysis] Beijing University Press. 2004.

Liu, Yinqiu, Shaoqin Zhao and Yanhong Liu. "Zi Zhu Chuang Xin Yu Min Ying Qi Ye Pin Pai Jing Zheng Li Ti Sheng" [Independent Innovation and the Upgrade of Brands in Private-owned Enterprises], Cai Mao Jing Ji [Finance and Trade Economics] Journal]. 2007, No. 1. pp. 76-82.

Main, Idabelle Lewis. "Christian Education", edited by Frank Rawlinson, The China Christian Year Book 1932-1933, Shanghai: Christian Literature Society. 1934.

Mauro, Paulo. "Corruption and Growth", Quarterly Journal of Economics, 1995, 110(3): 681-712. Myers, Ramon H. The Chinese Economy, Past and Present, Wadsworth, Belmont, California. 1980.

McArthur, John W. and Jeffrey D. Sachs. "Institutions and Geography: Comment on Acemoglu, Johnson and Robinson (2000)." NBER Working Paper No. 8114. 2001.

McCleary, Rachel M. and Robert J. Barro. "Religion and Political Economy in an International panel", Working Paper. 2003.

Molton T. Stauffer et al. The Christian Occupation of China: A General Survey of the Numerical Strength and Geographical Distribution of the Christian Forces in China Made by Special Committee on Survey and Occupation China Continuation Committee 1918-1921, Shanghai: 
China Continuation Committee. 1922.

Ni, Pengfei et al. Zhong Guo Cheng Shi Jing Zheng Li Bao Gao [Annual Report on Urban Competitiveness], China: Social Sciences Academic Press. 2003 and 2004.

North, Douglass C. and Thomas, Robert P. The Rise of the Western World: A New Economic History, Cambridge: Cambridge University Press. 1973.

North, Douglass C. Structure and Change in Economic History, New York: W.W. Norton $1 \&$ Co.. 1981.

North, Douglass C. Institutions, Institutional Change, and Economic Performance, Cambridge: Cambridge University Press. 1990.

Rodrik, Dani, Arvind Subramanian and Francesco Trebbi, "Institutions Rule: The Primacy of Institutions over Geography and Integration in Economic Development", Journal of Economic Growth, 2004, 131-165.

Romer, Paul. "Endogenous Technological Change", Journal of Political Economy, 1990, Vol. 98(5), "Part 2: The Problem of Development: A Conference on the Institute for the Study of Free Enterprise Systems." (Oct. 1990): S71-102. .

Sachs, Jeffrey D. and Andrew M. Warner. "Economic Reform and the Process of Global Integration", Brooking Papers on Economic Activity, 1995, 1-118.

Sachs, Jeffrey D. and Andrew M. Warner. "Sources of Slow Growth in African Economies", Journal of African Economies,1997, 6(3), 335-376.

Tang, Degang, Wan Qing Qi Shi Nian [The Last Seventy Years of Qing Dynasty]. China: Yue Lu Shu She. 2000. 
World Bank. "Governance, investment Climate, and Harmonious Society: Competitiveness Enhancements for 120 Cities in China”, 2006, Report No. 37759-CN.

Young, Alwyn. "Gold into Base Metals: Productivity Growth in the People's Republic of China During the Reform Period", Journal of Political Economy, 2003, Vol 111( 6): 1220-1261.

Yu, Yingshi. "Life and Immortality in the Mind of Han China", Harvard Journal of Asiatic Studies, Vol 25, 1964-1965. 
Table 1: Descriptive Statistics.

\begin{tabular}{lccc}
\hline \hline & Sample Mean & Minimum & Maximum \\
\hline Log GDP per capita in 2003 & 10.048 & 8.996 & 11.004 \\
& $(0.4842)$ & & 0.896 \\
Institution (Average protection of property rights & 0.6509 & 0.5035 & \\
2002-2003) & $(0.0979)$ & & \\
& & & \\
Christian lower primary $\quad$ school $\quad$ enrollment & 0.7225 & 0.0138 \\
(Enrollment in Christian missionary lower primary & $(0.8465)$ & & \\
schools in 1919) & & & \\
\hline
\end{tabular}

Note: The sample size for all variables is 47 . The standard deviations are reported in the parentheses under the means. 
Table 2: The Relationship between the Instrument and the Institutions in China.

Panel A. OLS: The Dependent Variable is log GDP per capita.

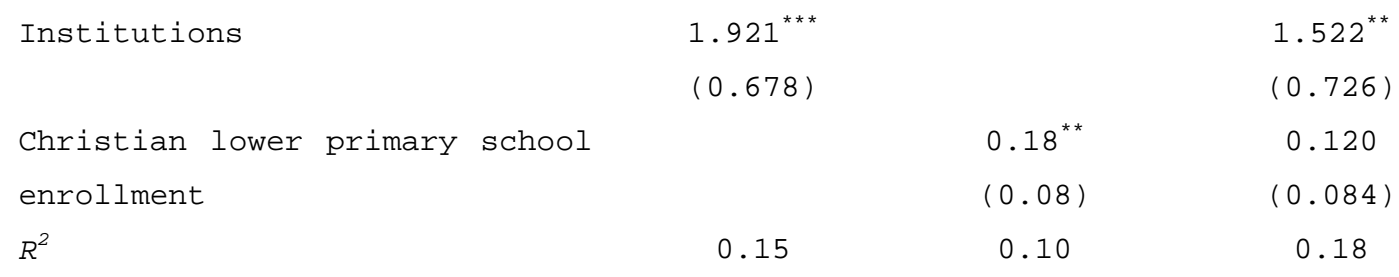

Panel B. OLS: The Dependent Variable is Institutions.

$\begin{array}{lccc}\text { Christian lower primary school } & 0.044^{* * *} & 0.036^{* *} & 0.051^{* * *} \\ \text { enrollment } & (0.015) & (0.015) & (0.015) \\ \text { Distance to the coast } & & -0.007^{* *} & \\ & & (0.002)\end{array}$

Investment rate in $2003 \quad 0.272^{*}$

$(0.137)$

$\begin{array}{llll}R^{2} & 0.14 & 0.25 & 0.21\end{array}$

Panel C. OLS: The Dependent Variable is Christian Lower Primary School Enrollment.

Distance to the coast $\quad-0.0374$

$(\odot .027)$

Total primary school enrollment 0.005

$(0.02)$

Investment rate in 2003

$-1.961$

(1.257)

$\mathrm{R}^{2}$

0.038

$\odot .001$

0.05

Note: Standard errors of estimated coefficients are in parentheses.

***: significant at $1 \%$

**: significant at $5 \%$

*: significant at $10 \%$ 
Table 3: The Effects of the Institutions on Economic Performance.

Panel A: 2SLS

\begin{tabular}{lc} 
Institutions & $4.230^{* *}$ \\
& $(1.940)$ \\
\hline Panel B: First-Stage Regression & \\
Christian lower primary school enrollment & $0.044^{* * *}$ \\
& $(0.015)$ \\
$R^{2}$ & 0.14 \\
$F$ & 7.77 \\
\hline Anderson canonical correlation LR test & 7.491 \\
$p$-Value & {$[0.006]$} \\
\hline
\end{tabular}

Notes: Panel A reports 2SLS estimates with the log GDP per capita in 2003 as the dependent variable, and Panel B reports the corresponding first-stage regression. Standard errors of estimated coefficients are in parentheses, and p-values are in brackets. The result from the overidentification test reports the Sargan's statistic.

$* * *$ : significant at $1 \%$

**: significant at $5 \%$

*: significant at $10 \%$ 
Table 4: Robustness Test with Additional Controls.

\begin{tabular}{|c|c|c|c|c|}
\hline & (1) & (2) & (3) & (4) \\
\hline \multicolumn{5}{|l|}{ Panel A: 2SLS } \\
\hline \multirow[t]{2}{*}{ Institutions } & $3.599^{*}$ & $4.304^{* *}$ & $4.115^{* *}$ & $3.621^{*}$ \\
\hline & $(2.184)$ & $(1.983)$ & $(1.954)$ & (2.119) \\
\hline \multirow[t]{2}{*}{ Distance to the coast } & -0.027 & & & -0.021 \\
\hline & $(0.024)$ & & & $(0.021)$ \\
\hline \multirow[t]{2}{*}{ Total primary school enrollment } & & -0.010 & & \\
\hline & & $(0.013)$ & & \\
\hline \multirow[t]{2}{*}{ Initial condition ( in 1985) } & & & 0.566 & 0.550 \\
\hline & & & $(0.542)$ & $(0498)$ \\
\hline \multicolumn{5}{|l|}{ Panel B: First-Stage Regression } \\
\hline \multirow[t]{2}{*}{ Christian lower primary school enrollment } & $0.036^{* *}$ & $0.043^{* * *}$ & $0.042^{* * *}$ & $0.037^{* *}$ \\
\hline & $(0.015)$ & $(0.015)$ & $(0.014)$ & $(0.014)$ \\
\hline \multirow[t]{2}{*}{ Distance to the coast } & $-0.007^{* *}$ & & & $-0.005^{* *}$ \\
\hline & $(0.002)$ & & & $(0.002)$ \\
\hline \multirow[t]{2}{*}{ Total primary school enrollment } & & 0.003 & & \\
\hline & & $(0.002)$ & & \\
\hline \multirow[t]{2}{*}{ Initial condition (in 1985) } & & & $0.196^{* * *}$ & $0.167^{* * *}$ \\
\hline & & & $(0.064)$ & $(0.064)$ \\
\hline$R^{2}$ & 0.25 & 0.19 & 0.29 & 0.35 \\
\hline
\end{tabular}

Notes: Panel A reports 2SLS estimates with the log GDP per capita in 2003 as the dependent variable, and Panel B reports the corresponding first-stage regression. Standard errors of estimated coefficients are in parentheses.

$* * *$ : significant at $1 \%$

**: significant at $5 \%$

*: significant at $10 \%$ 
Table 5: Robustness Tests with Different Institution Measurements.

(1)

Panel A: 2SLS

Average Protection of Property Rights

$4.23^{* *}$

(main specification)

Comprehensive Institutional Index

Index for government refrains of informal fees

$2.42^{*}$

\begin{tabular}{lccc}
\hline Panel B: First-Stage Regression & & \\
Average Protection of Property Rights & $0.044^{* * *}$ & & \\
(main specification) & $(0.015)$ & & \\
Comprehensive Institutional Index & & $0.033^{*}$ & \\
& & $(0.018)$ & \\
Index for government refrains of informal fees & & $0.077^{* *}$ \\
& & & $(0.029)$ \\
$R^{2}$ & 0.14 & 0.06 & 0.12 \\
\hline
\end{tabular}

Notes: Panel A reports 2SLS estimates with the log GDP per capita in 2003 as the dependent variable, and Panel B reports the first-stage regression with the listed institution measurement as the dependent variable for each specification. In Panel B, the explanatory variable is the instrument, that is, the enrollment in Christian missionary lower primary schools in 1919. Standard errors of estimated coefficients are in parentheses. The first column is our main specification in Table 3.

$* * *$ : significant at $1 \%$

**: significant at $5 \%$

*: significant at $10 \%$ 
Table 6: Geography versus Institutions.

\begin{tabular}{|c|c|c|c|c|c|}
\hline & (1) & (2) & (3) & (4) & (5) \\
\hline \multicolumn{6}{|l|}{ Panel A: 2SLS } \\
\hline \multirow[t]{2}{*}{ Institutions } & $3.559^{*}$ & $3.400^{*}$ & $3.949^{* *}$ & $3.950^{* *}$ & $3.479^{*}$ \\
\hline & $(1.874)$ & $(1.923)$ & $(1.867)$ & $(2.057)$ & $(1.932)$ \\
\hline \multirow[t]{2}{*}{ Latitude } & -0.016 & & & & 0.034 \\
\hline & $(0.011)$ & & & & $(0.060)$ \\
\hline \multirow[t]{2}{*}{ Temperature } & & $0.027^{*}$ & & & 0.712 \\
\hline & & $(0.016)$ & & & $(0.079)$ \\
\hline \multirow[t]{2}{*}{ Rainfalls } & & & 0.026 & & 0.004 \\
\hline & & & $(0.020)$ & & $(0.032)$ \\
\hline \multirow[t]{2}{*}{ North-south dummy } & & & & 0.142 & 0.016 \\
\hline & & & & $(0.178)$ & $(0.300)$ \\
\hline \multicolumn{6}{|l|}{ Panel B: First-Stage Regression } \\
\hline \multirow[t]{2}{*}{ Christian lower primary school enrollment } & $0.043^{* *}$ & $0.042^{* *}$ & $0.045^{* * *}$ & $0.040^{* *}$ & $0.042^{* *}$ \\
\hline & $(0.016)$ & $(0.016)$ & $(0.016)$ & $(0.015)$ & $(0.016)$ \\
\hline \multirow[t]{2}{*}{ Latitude } & -0.035 & & & & 0.016 \\
\hline & $(0.225)$ & & & & $(0.010)$ \\
\hline \multirow[t]{2}{*}{ Temperature } & & 0.001 & & & 0.018 \\
\hline & & $(0.003)$ & & & $(0.013)$ \\
\hline \multirow[t]{2}{*}{ Rainfall } & & & -0.002 & & -0.006 \\
\hline & & & $(0.003)$ & & $(0.005)$ \\
\hline \multirow[t]{2}{*}{ North-south dummy } & & & & 0.039 & $0.104^{* *}$ \\
\hline & & & & $(0.027)$ & $(0.046)$ \\
\hline$R^{2}$ & 0.14 & 0.14 & 0.15 & 0.14 & 0.28 \\
\hline
\end{tabular}

Notes: Panel A reports 2SLS estimates with log GDP per capita in 2003 as the dependent variable, and Panel B reports the corresponding first stage. Standard errors of estimated coefficients are in parentheses. The north-south dummy takes on a value of one when a city is located in Northern China and zero when is located in Southern China.

$$
\begin{aligned}
& * * * \text { : significant at } 1 \% \\
& \text { **: significant at } 5 \% \\
& \text { *: significant at } 10 \%
\end{aligned}
$$


Table 7: Policy versus Institutions

\begin{tabular}{|c|c|c|c|c|c|c|}
\hline & (1) & $(2)$ & (3) & (4) & (5) & (6) \\
\hline \multicolumn{7}{|l|}{ Panel A: 2SLS } \\
\hline \multirow[t]{2}{*}{ Institution } & $3.866^{*}$ & $4.405^{* *}$ & $4.249^{* * *}$ & $4.393^{* *}$ & $4.035^{*}$ & $3.383^{* *}$ \\
\hline & $(2.294)$ & $(2.098)$ & $(2.167)$ & $(2.302)$ & $(2.291)$ & $(1.534)$ \\
\hline \multirow[t]{2}{*}{ West dummy } & -0.413 & & & & & \\
\hline & $(0.320)$ & & & & & \\
\hline \multirow[t]{2}{*}{ East dummy } & 0.056 & & & & & \\
\hline & $(0.338)$ & & & & & \\
\hline \multirow[t]{2}{*}{ Dummy for coastal open cities } & & -0.119 & & -0.119 & & \\
\hline & & $(0.197)$ & & $(0.198)$ & & \\
\hline Dummy for provincial level and deputy & & & -0.004 & 0.002 & & \\
\hline provincial level cities & & & $(0.166)$ & $(0.165)$ & & \\
\hline \multirow[t]{2}{*}{ Government consumption/GDP } & & & & & 0.999 & \\
\hline & & & & & $(3.524)$ & \\
\hline \multirow[t]{2}{*}{ Investment rate in 2004} & & & & & & $-1.438^{* *}$ \\
\hline & & & & & & $(0.717)$ \\
\hline \multicolumn{7}{|l|}{ Panel B: First-Stage Regression } \\
\hline \multirow[t]{2}{*}{ Christian lower primary school enrollment } & $0.035^{* *}$ & $0.041^{* *}$ & $0.042^{* *}$ & $0.040^{* *}$ & $0.038^{* *}$ & $0.051^{* * * *}$ \\
\hline & $(0.015)$ & $(0.015)$ & $(0.016)$ & $(0.016)$ & $(0.016)$ & $(0.015)$ \\
\hline \multirow[t]{2}{*}{ West dummy } & 0.055 & & & & & \\
\hline & $(0.053)$ & & & & & \\
\hline \multirow[t]{2}{*}{ East dummy } & $0.107^{* * *}$ & & & & & \\
\hline & $(0.035)$ & & & & & \\
\hline \multirow[t]{2}{*}{ Dummy for coastal open cities } & & 0.040 & & 0.039 & & \\
\hline & & $(0.030)$ & & $(0.031)$ & & \\
\hline Dummy for provincial level and deputy & & & 0.012 & 0.009 & & \\
\hline provincial level cities & & & $(0.028)$ & $(0.028)$ & & \\
\hline \multirow[t]{2}{*}{ Government consumption/GDP } & & & & & 0.699 & \\
\hline & & & & & $(0.510)$ & \\
\hline \multirow[t]{2}{*}{ Investment rate in 2004} & & & & & & $0.272^{*}$ \\
\hline & & & & & & $(0.137)$ \\
\hline$R^{2}$ & 0.30 & 0.17 & 0.15 & 0.18 & 0.18 & 0.21 \\
\hline
\end{tabular}

Notes: Panel A reports 2SLS estimates with the log GDP per capita in 2003 as the dependent variable, and Panel B reports the corresponding first-stage regression. Standard errors of estimated coefficients are in parentheses. In column (1), the dummy for cities in middle China is omitted in the regression.

*** significant at $1 \%, * *$ significant at $5 \%$, significant at $10 \%$. 
A1: Data Descriptions and Sources.

\begin{tabular}{|c|c|}
\hline Data Descriptions & Sources \\
\hline Log GDP per capita in 2003 & From the Urban statistical Yearbook of China (2004) \\
\hline $\begin{array}{l}\text { Institutions } \\
\text { (Average protection of property rights, 2002-2003) }\end{array}$ & From Ni (2004 and 2005) \\
\hline $\begin{array}{l}\text { Christian lower primary school enrollment } \\
\text { (Enrollment in Christian missionary lower primary } \\
\text { schools per } 1,000 \text { persons in 1919) }\end{array}$ & From the Continuation Committee (1922) \\
\hline Distance to the coast & From Au and Henderson (2002) \\
\hline $\begin{array}{l}\text { Total primary school enrollment (Enrollment in } \\
\text { missionary and government primary schools per } 1,000 \\
\text { persons in 1919) }\end{array}$ & From the Continuation Committee (1922) \\
\hline $\begin{array}{l}\text { Initial condition } \\
\text { ( } \text { Log national income per capita in } 1985^{1} \text { ) }\end{array}$ & From the Urban statistical Yearbook of China (1986) \\
\hline $\begin{array}{l}\text { Christian higher primary school enrollment (Enrollment } \\
\text { in Christian missionary higher primary schools per } \\
1,000 \text { persons in 1919) }\end{array}$ & From the Continuation Committee (1922) \\
\hline Latitude & From Au and Henderson (2002) \\
\hline Temperature (Average in centigrade) & From various Provincial Statistical Yearbook of China (2004) \\
\hline Rainfall (in millimeters) & $\begin{array}{l}\text { From the various Provincial Statistical Yearbooks of China } \\
\text { (2004) }\end{array}$ \\
\hline $\begin{array}{l}\text { The ratio between government consumption and GDP in } \\
2003^{(2)}\end{array}$ & From the Urban statistical Yearbook of China (2004) \\
\hline
\end{tabular}

Note: (1) National income = gross agricultural value + value added in industry

(2) Government consumption is the net government spending on expenditures on education, science and social security. 
A2: Main Data Used in the Paper.

\begin{tabular}{|c|c|c|c|c|c|c|c|}
\hline Cities & $\begin{array}{l}\text { Log GDP } \\
\text { per capita } \\
\text { in } 2003\end{array}$ & $\begin{array}{l}\text { Institutions } \\
\text { (Average } \\
\text { protection of } \\
\text { property } \\
\text { rights } \\
2002-2003 \text { ) }\end{array}$ & $\begin{array}{l}\text { Instrument } \\
\text { (Enrollment in } \\
\text { Christian } \\
\text { missionary } \\
\text { lower primary } \\
\text { schools per } \\
100,000 \\
\text { persons in } \\
1919)\end{array}$ & Cities & $\begin{array}{l}\text { Log GDP } \\
\text { per capita } \\
\text { in } 2003\end{array}$ & $\begin{array}{l}\text { Institutions } \\
\text { (Average } \\
\text { protection of } \\
\text { property } \\
\text { rights } \\
2002-2003 \text { ) }\end{array}$ & $\begin{array}{l}\text { Instrument } \\
\text { (Enrollment in } \\
\text { Christian } \\
\text { missionary } \\
\text { lower primary } \\
\text { schools per } \\
\text { 100,000 } \\
\text { persons in } \\
\text { 1919) }\end{array}$ \\
\hline Shenzhen & 10.90678 & 0.716 & 3.354157 & Guangzhou & 10.78668 & 0.5265 & 0.81036 \\
\hline Wenzhou & 9.714625 & 0.703 & 0.363966 & Yantai & 9.914477 & 0.656 & 1.352353 \\
\hline Ningbo & 10.39326 & 0.874 & 0.605413 & Chongqing & 8.996776 & 0.612 & 0.207788 \\
\hline Shanghai & 10.75188 & 0.8575 & 0.867647 & Chengdu & 9.800956 & 0.662 & 0.657268 \\
\hline Jiaxing & 10.15782 & 0.768 & 0.236241 & Weihai & 10.42709 & 0.5495 & 0.389025 \\
\hline Huzhou & 9.857548 & 0.672 & 0.375335 & Zhuhai & 10.984 & 0.68 & 0.744186 \\
\hline Shaoxing & 10.13122 & 0.8105 & 0.342742 & Nanchang & 9.573733 & 0.625 & 0.304401 \\
\hline Zhongshan & 10.50819 & 0.6675 & 0.744186 & Hefei & 9.279866 & 0.5585 & 0.123119 \\
\hline Taizhou & 9.800402 & 0.6095 & 0.202358 & Shijiazhuang & 9.628261 & 0.614 & 0.033106 \\
\hline Suzhou & 10.77254 & 0.7565 & 0.566417 & Dalian & 10.28213 & 0.632 & 0.204756 \\
\hline Xiamen & 10.46336 & 0.896 & 4.202231 & Changsha & 9.603058 & 0.5515 & 0.580194 \\
\hline Hangzhou & 10.39876 & 0.716 & 0.807204 & Haikou & 9.724959 & 0.5675 & 0.322727 \\
\hline Qingdao & 10.06041 & 0.824 & 2.674683 & Xi'an & 9.411892 & 0.646 & 0.520519 \\
\hline Beijing & 10.3754 & 0.679 & 1.222187 & Kunming & 9.699656 & 0.5295 & 0.640646 \\
\hline Dongguan & 11.00473 & 0.6365 & 0.707389 & Tianjin & 10.18611 & 0.641 & 0.415557 \\
\hline Zhoushan & 9.780133 & 0.699 & 0.216511 & Wuhan & 9.973806 & 0.5035 & 1.198144 \\
\hline Nantong & 9.466841 & 0.7255 & 0.013829 & Fuzhou & 9.929155 & 0.5805 & 2.4713 \\
\hline Changzhou & 10.17157 & 0.641 & 0.303127 & Shenyang & 10.05496 & 0.5195 & 0.597351 \\
\hline Wuxi & 10.67255 & 0.6825 & 0.32671 & Changchun & 9.836546 & 0.58 & 0.133644 \\
\hline Quanzhou & 9.820867 & 0.608 & 1.233659 & Qinhuangdao & 9.563529 & 0.689 & 0.637698 \\
\hline Foshan & 10.60767 & 0.646 & 0.141509 & Haerbin & 9.607236 & 0.5325 & 0.26263 \\
\hline Nanjing & 10.2149 & 0.7195 & 0.875139 & Zhengzhou & 9.744668 & 0.517 & 0.19503 \\
\hline Jinan & 10.06858 & 0.633 & 0.336659 & Xuzhou & 9.20954 & 0.524 & 0.292204 \\
\hline Huizhou & 9.940687 & 0.558 & 0.148392 & & & & \\
\hline
\end{tabular}

